RESEARCH ARTICLE

\title{
Spotted fever group rickettsia in ticks infesting humans, wild and domesticated animals of Sri Lanka: one health approach
}

\author{
D. R. Liyanaarachchi ${ }^{1 *}$, R. S. Rajakaruna ${ }^{2}$, and R. P. V. J. Rajapakse ${ }^{1}$ \\ ${ }^{1}$ Department of Veterinary Pathobiology, Faculty of Veterinary Medicine and Animal Science, University of \\ Peradeniya, Sri Lanka. \\ ${ }^{2}$ Department of Zoology, Faculty of Science, University of Peradeniya, Sri Lanka. \\ Accepted December 31, 2015
}

\begin{abstract}
Spotted fever group rickettsial infections are considered an emerging infectious disease in Sri Lanka. The present study examined the potential role of tick vectors carrying the infection from sylvatic reservoirs to humans via domesticated animals. Ticks infesting humans, dogs and wild animals were collected island-wide and were identified. Presence of spotted fever group rickettsia in the tick blood meal was determined using PCR in a sub-sample of ticks collected. A total of 30,933 ticks were collected from 30 different hosts and free living stages from the ground. The collection consisted of 25 tick species recording 12 species from humans, 19 from domesticated animals and 22 from wild animals. Of the total collection, randomly selected sub-sample of 80 ticks were used to identify rickettsia pathogens. This comprised of fifty ticks from 50 wild animals belonged to 15 species (wild boar, pangolin, porcupine, barking deer, star tortoise, mouse deer, samber, spotted deer, monkey, civet cat, bandicoot, elephant, fishing cat, rabbit, flying squirrel; and 20 ticks from 15 dogs especially from areas where spotted fever cases were reported and 10 ticks from 10 humans. Results showed that rickettsial infections were found in four tick species, Amblyomma testudinarium collected from a wild boar, Riphicephalus sanguineus from a dog, Amblyomma clypeolatum from a star tortoise and Amblyomma javanense from a pangolin. Except for A. javanense, other three tick species are generalists infesting humans as well as domestic and wild animals. There is a high potential that these infections can spread easily to humans via the domesticated animals. This is the first report of ticks infesting domesticated and wild animals carrying spotted fever rikettsia and it underscores the possibility of spread of infection from wild reservoirs to human in the animal/human health interface.
\end{abstract}

Keywords: ticks, zoonoses, domesticated animals, wildlife, spotted fever rickettsia

\section{INTRODUCTION}

Tick-borne diseases recorded in humans include rickettsioses, ehrlichiosis, babesiosis, Kyasaunur forest disease, typhus fever varieties, haemoragic fever varieties, tick borne encephalitis, Lyme disease and Q fever (Jongejan and Uilenberge, 2004). Most of these tick-borne infections emerge from the wild reservoir (Daszak et al., 2001) and approximately $10 \%$ of the currently known 867 tick species act as vectors of a broad range of pathogens of domestic animals (Jongejan and Uilenberge, 2004).Ticks and tick-borne infections have coevolved with wild reservoirs which often live in a state of equilibrium but constitute a constant reservoir of infections to domesticated animals and humans. These wild hosts come into contact with domesticated animals when man moves livestock into infested regions, or moved livestock infested with the ticks into previously uninfected regions (Jongejan and Uilenberge, 2004).
Life cycle of tick-borne pathogens is highly dependent on tick ecology which is one of the most important factors driving the epidemiology of tickborne diseases (Randolph, 2009). In preventing emergence of tick-borne diseases, role of wildlife as tick hosts and their role in the life cycle of tickborne pathogens is considered important. Some tick species may be generalists and may feed on different vertebrate species depending on their availability and abundance (Wilson et al., 1984) whereas other species may be more specific and use a narrow host range (Sonenshine et al., 2002). Wild and domestic cycles are often complementary. Immature tick stages that parasitize wild and peri-domestic animals can feed later as adults on domesticated animals. Thus, investigating the role of wildlife as tick hosts is of great relevance for understanding the epidemiology of tick-borne diseases shared with domesticated animals and humans (Ruiz-Fons et al., 2006; Ruiz-Fons and Gilbert, 2010).

*Corresponding author’s email: rupikar@pdn.ac.lk 
The spotted fever rickettsiae are zoonotic where the pathogens circulate in enzoonotic or occasionally epizoonotic cycles, between wild vertebrates and their tick vectors (Walker and Fishbein, 1992). According to Rudakov et al. (2003) the pathogen has natural cycles with parasitic systems that involve many wild mammals, tick vectors, and long term reservoirs of rickettsiae. Secondly, they also have domestic or anthropogenic cycles that involve domestic animals, especially dogs. People are an accidental host in the circulation and maintenance of the pathogen. These pathogens will mutate quickly and have shown a broad degree of severity especially in humans (Rudakov et al., 2003). Humans are only occasional hosts for ticks and rarely play a role in the subsequent transmission of bacteria. Therefore, human should be viewed as a 'dead end' host, which plays no role in the maintenance of these bacteria in nature (Parola and Raoult, 2001).

Rickettsial infections have been reported in patients from the Central (Kularatne et al., 2003) and Western (Premaratne, 2008) provinces of Sri Lanka as an emerging infection. Recently, Weerakoon et al. (2011a; b) recorded 220 IFA confirmed patients with rickettsial infections from the Teaching Hospital,Peradeniya during 2008 to 2010.These patients were found positive for three ricketsia species namely, Rickettsia conorii, Orientia tsutsugamushi and Rickettsia typhi of which $91 \%$ being $R$. conorii with high number of mixed infections (Weerakoon et al., 2011a,b).The reservoir and the vector of rickettsia in Sri Lanka are largely unknown. Some of the tick species reported from Sri Lanka are known vectors of rickettsia in the world. Lack of knowledge in the infectious agents carried by tick species of Sri Lanka, and sylvatic and domestic reservoirs and the zoonotic potential of tick-borne spotted fever group rickettsia prompted us to carry out the present study.

Molecular methods based on polymerase chain reaction (PCR) have enabled the development of sensitive, specific and rapid tools for both detection and identification of rickettsiae from various samples. Clinical specimens and arthropod tissues could be used to detect rickettsia by PCR. For rickettsioses, detection strategies based on recognition of sequences within the genes encoding the $17 \mathrm{kDa}$ protein (Paddock et al., 2006; Weinberg et al., 2008). PCR assays for rickettsial species are carried out amplifying genes $17 \mathrm{kDa}$ for spotted fever group (Eremeeva and Bosserman, 2006). The gene encoding $17 \mathrm{kDa}$ protein shows high homology among the spotted fever group (SFG) and typhus group (TG) rickettsiae and therefore, the protocol used to detect spotted fever causing pathogens targets the $17 \mathrm{kDa}$ antigen gene for detection of several species of ricketssiae. The protein encoded by this gene is referred to as the genus - common antigen and is found in species of both the spotted fever and typhus groups.

According to Tzianabos et al. (1989) a nested PCR protocol that uses broad range primers R17 - 122 (CAGAGTGCTATGAACAAACAA GG) and R17 - 500 (CTTGCCATTGCCCATCAG GTTG) in the primary stage and separate pairs of more specific primers are used in the nested stage. TZ15 (TTCTCAATTCGGTAAGGGC:208-247 bp) and TZ16(ATATTGACCAGTGCTATTTC: 208 - 247) are used for detection of $R$. ricketsii, and several closely related species of the spotted fever group and RP2 and RP1D for detection of Rickettsia typhi and Rickettsia prowazeki (Tzianabos et al., 1989).

\section{MATERIALS AND METHODS}

\section{Collection of ticks}

An island-wide collection of ticks infesting humans, dogs and wild animals was carried out during January 2009 to August 2011 and were identified. Of the collection, a sub sample of ticks was used to analyse the presence of spotted fever rickettsial infections. Ticks were collected from injured or dead wild animals which were brought to veterinary hospitals or clinics in Kandy and to wildlife parks at Minipe, Mihintale, Udawalawa, Buttala, Randenigala, Yala and Wasgamuwa. Ticks infesting human ear canal were also collected from the Ear, Nose, Throat (ENT) clinic at Suwasewana Private Hospital in Kandy and through civilians in the Central Province. Ticks were preserved in $70 \%$ ethanol and brought to the laboratory in the Department of Veterinary Pathobiology, Faculty of Veterinary Medicine and Animal Health at the University of Peradeniya, Sri Lanka and identified using light microscope and available keys and literature (Nuttall et al., 1915; Sharif, 1928; Trapido et al., 1963; Seneviratne, 1965).Different stages (larvae, nymphs, and adults) and sex of adult ticks were also noted down.

\section{Identification of spotted fever rickettsial infections in ticks by nested PCR}

Eighty ticks from the total tick collection including 50 ticks from wild animals such as wild boar, pangolin, porcupine, barking deer, star tortoise, mouse deer, samber, spotted deer, monkey, civet cat, bandicoot, elephant, fishing cat, rabbit, flying squirrel) and 20 ticks from dogs $(n=15)$ especially those from spotted fever infected areas and 10 ticks from human ear canal were used to study the presence of spotted fever rickettsial infections.

\section{Isolation of genomic DNA}

Ticks were placed separately in centrifuge tubes and washed with PBS solution to remove ethanol and set to air dry overnight. They were cut into 
small pieces separately using clean fine blade and were crushed with a plastic pestle. From these, the $17 \mathrm{kDa}$ antigen gene ( $h$ tr gene) for spotted fever rickettsia was isolated and amplified (Tzianabos et al., 1989).

Genomic DNA was extracted using wizard DNA purification kit (Promega, USA). For each sample $120 \mu 1$ of 0.5 EDTA solution ( $\mathrm{pH} \mathrm{8.0)}$ ) and $500 \mu \mathrm{l}$ of nuclei lysis solution were taken. Nuclei lysis solution and EDTA for 10 samples were collectively placed in a large tube and chilled on ice for $5 \mathrm{~min}$ until it turned cloudy. Then $600 \mu \mathrm{l}$ of EDTA/nuclei lysis solution was added to centrifuge tubes containing crushed ticks and $8 \mu \mathrm{l}$ of Proteinase $\mathrm{K}$ was added to each. Tubes were incubated overnight in a heat block at $55^{\circ} \mathrm{C}$. For each sample $200 \mu \mathrm{l}$ of protein precipitation solution was added and vortexed vigorously at high speed for 20 seconds. All the samples were chilled for 5 min and centrifuged at $16,000 \mathrm{~g}$ for $4 \mathrm{~min}$. The supernatant was removed carefully into a clean centrifuge tube containing $600 \mu \mathrm{l}$ isopropanol and gently mixed by inversion. Tubes were again centrifuged at $16,000 \mathrm{~g}$ for $1 \mathrm{~min}$. The supernatants were carefully decanted. To each tube $600 \mu \mathrm{l}$ of $70 \%$ ethanol was added gently, inverted several times to mix and was centrifuged again at $16,000 \mathrm{~g}$ for $1 \mathrm{~min}$. Ethanol was carefully aspirated using a Pasteur pipette and the tubes were kept inverted for 15 min. DNA rehydration solution $(50 \mu \mathrm{l})$ was added to each tube and incubated at $65^{\circ} \mathrm{C}$ for $1 \mathrm{hr}$ and stored at $4{ }^{\circ} \mathrm{C}$. Extractions were used to identify pathogens of spotted fever using appropriate primers and PCR.

\section{Amplification of $17 \mathrm{kDa}$ antigen gene for rickettsia}

PCR-master mix was prepared by adding $0.25 \mu$ lTaq, $2.5 \mu$ l Buffer, $2 \mu \mathrm{ldNTP}, 1.5 \mu \mathrm{l}$ of each primer. Primers used for the outer PCR were R17 - 122 (F) with gene sequence of CAGAGTGCTATGAACAAACAAGG and R 17 $500(\mathrm{R})$ with gene sequence CTTGCCATTGCC CATCAGGTTG and for the nested stage TZ $15(\mathrm{~F})$ TTCTCAATTCGGTAAGGGC and TZ (R) ATATTGACCAGTGCTATTTC. Aliquots of the master mix were transferred into each PCR tube and templates were added to each. The PCR reactions were performed in a PCR machine (MIKRO 24-48R) in a final volume of $25 \mu \mathrm{l}$ using the master mix with templates. Thermocycler parameters to amplify $17 \mathrm{kDa}$ antigen gene for rickettsia were $95{ }^{\circ} \mathrm{C}$ for initial denaturation $(5$ $\min ), 95{ }^{\circ} \mathrm{C}$ for denaturation $(30 \mathrm{sec}), 55^{\circ} \mathrm{C}$ for annealing $(30 \mathrm{sec}), 72{ }^{\circ} \mathrm{C}$ for extension $(60 \mathrm{sec})$, and $60 \mathrm{sec}$ for final extension $(5 \mathrm{~min})$. The parameters are identical to those of the primary stage with the exception that the number of cycles is 30 for primary stage and 40 for nested stage (Tzianabos et al., 1989). Products from PCR were analysed using gel electrophoresis.

\section{Agarose gel electrophoresis}

Products from PCR were analysed using gel electrophoresis. Mini gels $(50 \mathrm{ml})$ containing $2 \%$ agarose (Promega Agarose Madison, USA) in 1X TAE buffer ( $\mathrm{pH}$ 8.0) were prepared. PCR products were mixed with loading buffer (bromphenol blue) in a proportion 10:3 (PCR products: loading buffer) and loaded into the ethidium bromide $(0.5 \mu \mathrm{g} / \mathrm{ml})$ stained gels. DNA products were electrophoresed at $100 \mathrm{~V}$ at TAE buffer until an appropriate separation of the PCR products was achieved. A $100 \mathrm{bp}$ DNA marker ladder was used as standards for detection of the PCR products. The electrophoresed gel was observed under UV light (Gel documentation system, Vilber Lourmat, 77202 Marne laVallee, France). Gels were digitized using a camera-based documentation system (IBM PC Camera, USA) and the respective Multi Analysis software (IBM Odyssey multimedia, USA).

\section{RESULTS AND DISCUSSION}

A total of 30,461 ticks were collected from humans $(\mathrm{n}=75)$, domestic animals $(\mathrm{n}=25,566)$, wild animals $(\mathrm{n}=1,385)$ and free living stages from the ground $(n=3435)$. The collection consisted of 22 different tick species belonging to seven genera including Rhipicephalus, Haemaphysalis, Amblyomma, Hyalomma, Dermacentor, Nosomma, and Ixodes. There were 12 species of ticks from humans, 19 from domesticated animals and 21 from wild animals (Appendix 1). Due to the high cost of analysis only eighty ticks were selected (Figure 1) from the whole collection to analyse for the rickettsial pathogen. Eighteen tick species belonging to seven genera infesting humans and dogs and 15 tick species of wild animals were analysed. Out of 80 ethidium-bromide stained gel electrophoreses with PCR products (208 bp), only four ticks $(5 \%)$ were positive for spotted fever infections (Appendix 1). These include three Amblyomma species: Amblyomma testudinairum taken from a wild boar (Sus cristatus cristatus), Amblyomma clypeolatum from a star tortoise, and Amblyomma javanense from a pangolin and Rhipicephalus sanguineus from a dog. Except for A. javanense other three tick species infest humans (Liyanaarachchi et al., 2015a) which shows that all these tick species positive for spotted fever rickettsia could act as a vector spreading the infection from reservoirs to humans. 


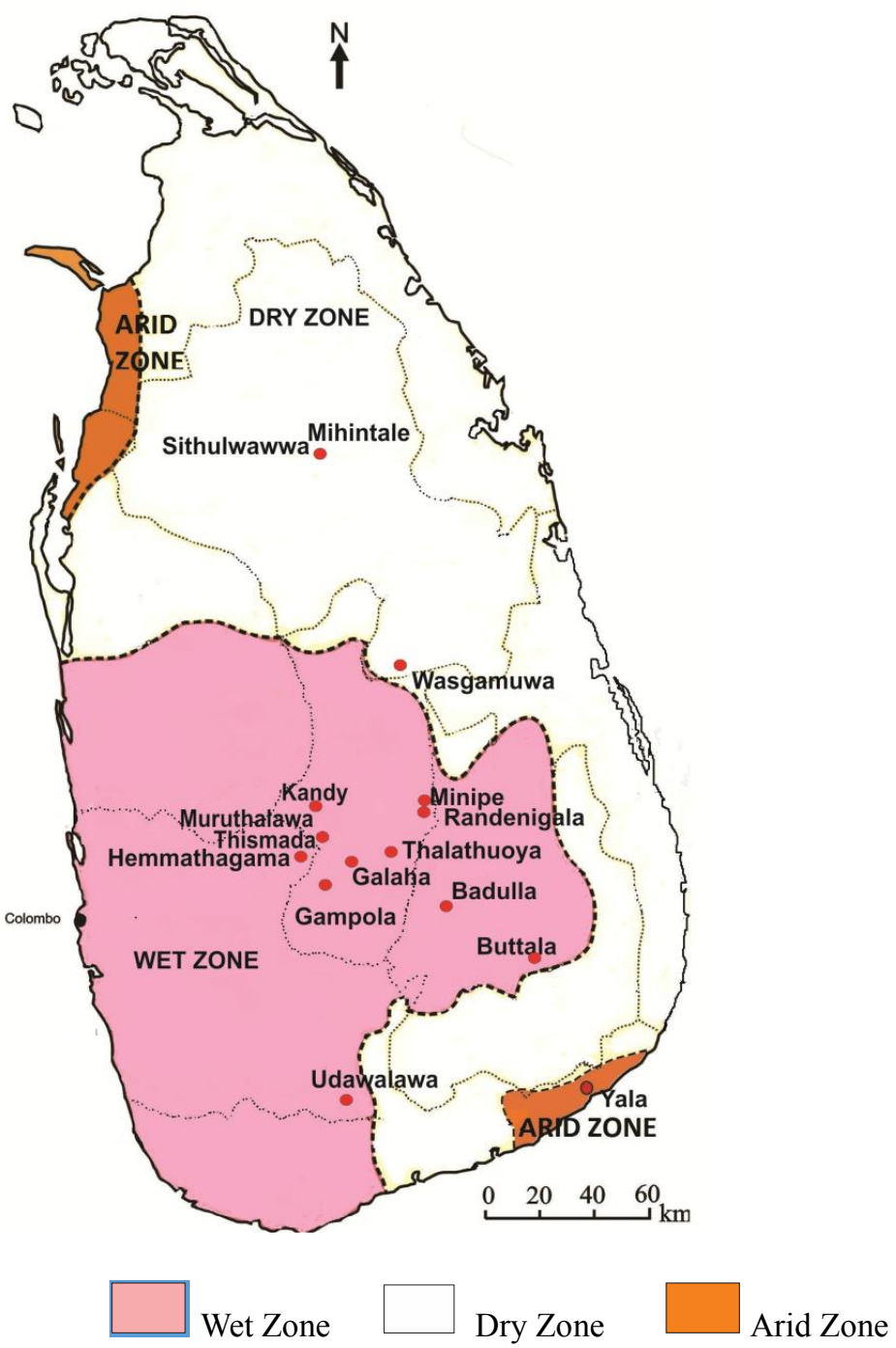

Figure 1. Locations of collection sites of wild and domesticated animal in Sri Lanka

Moreover, dogs carry $A$. testudinarium, $A$. clypeolatum and $R$. sanguinus (Liyanaarachchi et al., 2015b) and therefore there is a possibility that humans acquire these infections from the wild reservoirs via dogs.

In Sri Lanka, wild boar is distributed island-wide. A substantial increase in numbers of wild boar has been observed in domestic and peri-domestic areas due to recent law enforcement by the Department of Wildlife Conservation restricting the killing of wild boars for meat (personal communication with villagers). The most common tick on wild boar is A. testudinarium (Liyanaarachchi et al., 2015b) and of the five specimens analysed from wild boars, one was positive for rickettsial infections. It is also the second most common tick species on humans and also infests dogs (Ariyaratne et al. 2010; Liyanaarachi et al., 2015b).
Moreover, wild boar is the preferred host of adult Dermacentor auratus which has a three host life cycle where dogs carry the larvae of $D$. auratus (Liyanaarchchi et al., 2013). The nymphal stage of $D$. auratus has been identified as the most common tick species infesting humans (Edussuriya and Weilgama, 2003; Ariyaratne et al., 2010). Although the two specimens of $D$. auratus did not carry the infection, there is a high possibility that it can carry the infection from the wild boars to dogs and then to humans. When the wildboars roam the neighborhoods in the night, they bring the engorged females with the infection. These females drop off and lay eggs in the compound and the larvae that hatch out from the eggs can be easily picked by dogs and thereby spread to humans as well since these infections are transovarian (Macaluso et al., 2001; 2002; Horta et al., 2006; Socolovschi et al., 2009). 
Amblyomma testudinarium is a generalist infesting humans, many domesticated animals such as dogs, cattle, buffalo, goat, cat and domestic fowl and wild animals such as mouse deer, sambar, pangolin, and elephant in addition to wild boar (Liyanaarachchi et $a l, 2015 b)$.In the dry zone of Sri Lanka farmers who rear livestock, especially cattle, buffalo and goat, releasing them during the day time to graze in the nearby forests is a common practice. The spread of ticks and the infections they carry can also occur when they return to their resting places in the evening with the ticks they picked from wildlife.

In recent years many factors have changed the interactions among humans, animals and the environment and this has caused the emergence and reemergence of many diseases. Human populations are growing and expanding into new geographic areas. As a result, more people live in close contact with wild and domestic animals. This provides more opportunities for diseases to pass between animals and people. In Sri Lanka, there is a considerable increase in the number of wildlife roaming in villages had even in urban and semi-urban neighborhoods because of habitat destruction due to forest fragmentation and farming practices. This increases the interactions of wild animals with domesticated animals. Wild animals such as wild boar, monkey, mouse deer, barking deer, pangolins, civet cats, fishing cats, porcupines and elephants recently have become peri-domestic animals in Sri Lanka (Personal communications with civilians). Most of the tick species that were collected from domesticated animals during the present study (Liyanaarachchi et al., 2015b) were previously recorded only from wild animals (Seneviratne, 1965). Introduction of new tick species to domestic stock reveals that they are vulnerable to infections which prevail in wild.

This study provides evidence that spotted fever group rickettsial infections could be a potentially a tick-borne zoonotic disease and underscores the importance making an effort to reduce risk of the animal/human health interface. It should also be noted that the problem does not flow in one direction, so that in addition to considering the risks posed by wildlife for domesticated animals, it is also necessary to consider domesticated animals as source of risk to wildlife. Disruption in environmental conditions and habitats provides new opportunities for new diseases to pass to animals from humans and domestic animals and vise versa.

\section{ACKNOWLEDGEMENTS}

Authors thank Dimitry A. Apanaskevich of Georgia Southern University, USA for confirming the identity of some tick species. Financial support from Gate Mudaliar A.G. Thilakaratne Research
Fellowship, National Research Council (Grant No 09-05) aregreatly appreciated. Authors also wish to thank Dr. B.D. Edusuriya for providing ticks infested in human ear canal, and all veterinarians and volunteers who helped in the collection of ticks.

\section{REFERENCES}

Ariyarathne,S., Rajakaruna, R.S., Ekanayake, D.H., Dilrukshi, P.R.M.P. and Amerasinghe P.H. (2010). Occurrence and distribution of tick species associated with human otoacariasis in selected districts of Sri Lanka. Proceedings of Peradeniya University Research Sessions 15: 347-349.

Socolovschi1,C., Huynh, T.P., Davoust, B., and Gomez, J. (2009). Transovarial and transstadial transmission of Rickettsiaea fricae in Amblyomma variegatum ticks. Clinical Microbiological Infections 15: Supplement 2.

Daszak, P., Cunningham, A.A. and Hyatt A.D. (2001). Anthropogenic environmental change and the emergence of infectious diseases in wildlife. Acta Tropica 78:103116.

Edussuriya, B.D. and Weilgama, D.J. (2003). Case reports: intra-aural tick infestations in humans in Sri Lanka. Transactions of Royal Society of Medicine and Hygiene 97: 412413.

Eremeeva, M., and Bosserman,E.A. (2006).Molecular typing of novel Rickettsia rickettsii isolates from Arizona. Annals of New York Academy of Science 1078, 573577.

Horta, M.C., Pinter, A., Schumaker, T.T., and Labruna, M.B. (2006). Natural infection, transovarial transmission, and transstadial survival of Rickettsia bellii in the Tick Ixodes loricatus (Acari: Ixodidae) from Brazil. Annals of New York Academy of Science 1078: 285-90.

Jongejan, F. and Uilenberge, G. (2004).The global importance of ticks. Parasitology129: 3-14.

Kularatne, S.A.M., Edirisinghe, J.S., Gawarammana, I.B. and Urakami, H. (2003). Emerging rickettsial infections in Sri Lanka: the pattern in the hilly Central Province. Tropical Medicine and International Health 8: 803-811.

Liyanaarachchi, D.R., Jinadasa, H.R.N., Dilrukshi, P.R.M.P., and Rajapakse, R.P.V.J.(2013). Epidemiological Study on Ticks in Farm Animals in Selected Areas of Sri Lanka. Tropical Agricultural Research 24: 336-346.

Liyanarachchi, D.R., Rajakaruna, R.S., Dikkumbura, A.W., De Silva, A. and Rajapakse, R.P.V.J. (2015a). Ticks (Acarina: 
Ixodida) infesting five reptile species in Sri Lanka with sixteen new host records. Zootaxa 3964: 146-148.

Liyanaarachchi, D.R., Rajakaruna, R.S., Dikkumbura, A.W. and Rajapakse, R.P.V.J. (2015b). Ticks infesting wild and domestic animals and humans of Sri Lanka with new host records. Acta Tropica 142:64-70.

Macaluso, K.R., Sonenshine, D.E. Ceraul, S.M. and Azad, A.F. (2001). Infection and transovarial transmission of rickettsiae in Dermacentor variabilis ticks acquired by artificial feeding. Vector Borne Zoonotic Diseases 1:45-53.

Macaluso, K.R., Sonenshine, D.E., Ceraul, S.M. and Azad, A.F. (2002). Rickettsial infection in Dermacentor variabilis (Acari: Ixodidae) inhibits transovarial transmission of a second Rickettsia. Journal of Medical Entomology 39: 809-13.

Nuttall, G.H.F., Warburton, C., Cooper, W.F. and Robinson, L.E. (1915). The genus Haemaphysalis. Ticks: Amonograph of the Ixodidea. Part 111.Cambridge University Press. pp. 351- 550.

Paddock, C.D., Koss, T., Eremeeva, M.E., Dasch, G.A., Zaki, S.R., and Sumner, J.W. (2006). Isolation of Rickettsia akari from eschars of patients with rickettsial pox.American Journal of Tropical Medicine and Hygiene 75 (4), 732-738.

Parola, P. and Raoult, D.(2001). Ticks and tickborne bacterial diseases in humans: an emerging infectious threat. Clinical Infectious Diseases 32:897-928.

Premaratna, R., Loftis, A.D., Chandrasena, T.G.A.N., and Dasch, G.A. (2008). Rickettsial infections and their clinical presentation in the Western Province of Sri Lanka: a hospital- based study. Journal of Infectious Diseases 12:198-202.

Randolph, S.E. (2009). Tick-borne disease systems emerge from the shadows: the beauty lies in molecular detail, the message in epidemiology. Parasitology 136:14031413.

Rudakov, N.V., Shpynov, S.N., Samoilenko, I.E. and Tankibaev, M. A. (2003).Ecology and epidemiology of spotted fever group Rickettsiae and new data from their study in Russia and Kazakhstan. New York Academy of Science 990: 12-24.

Ruiz-Fons, F. and Gilbert, L. (2010). The role of deer as vehicles to move ticks Ixodes ricinus between contrasting habitats. International Journal of Parasitology 40:1013-1020.

Ruiz-Fons, F., Fernández-de-Mera, I.G., Acevedo, P. and Höfle, U. (2006). Ixodid ticks parasitizing Iberian red deer (Cervus elaphushispanicus) and European wild boar
(Sus scrofa) from Spain: geographical and temporal distribution. Veterinary Parasitology 140:133-142.

Seneviratne, P.(1965). The Ixodidae (Ticks) of Ceylon. Part II and III. Ceylon Veterinary Journal 13(2): 28-45.

Sharif, M. (928). A revision of the Indian Ixodidae, with special reference to the collection in the Indian Museum. Records of Indian Museum 30: $217-344$.

Sonenshine, D.E, Lane, R.S., and Nicholson, W.L.(2002). Ticks (Ixodida). In: Mullen, G., Durden, L.(Eds.), Medical and Veterinary Entomology. Academic Press, Orlando. pp.; 517-558.

Trapido, H.P.K., Hoogstraal, H. and Verma, M.G.R. (1963). Redescription of the Holotype and Description of all types of Haemaphysalis turturis.Nuttal and Warburton from Ceylon and India (Ixodoidae, Ixodidae). Journal of Parasitology 49: 678-685.

Trapido, M., Varma, M.G.R., Rajagopalan, P.K. and Singh, K.R.P. (1964). Guide to the identification of all stages of all Haemaphysalis ticks of South India. Bulletin of Entomological Research 55:249-270.

Tzianabos, T., Anderson, B.E, and McDade, J.E.(1989). Detection of Rickettsia rickettsii in clinical specimens by using Polyrnerase Chain Reaction technology. Journal of Clinical Microbiology 27: 2866-2868.

Walker, D .H. and Fishbein, D. B. (1992). Epodemology of rickettsial disease. European Journal of Epidimiology 7:237245.

Weerakoon, K.G.A.D., Rajapakse, R.P.V.J., Adikari, S.B. and Medagedara, S.C. (2011a). Clinical and Laboratory Features of Spotted Fever Rickettsioses in Patients Presented to Teaching Hospital, Peradeniya. Proceedings of Peradeniya University Research Sessions $\mathrm{P} 100$.

Weerakoon, K.G.A.D., Rajapakse, R.P.V.J., Adikari, S.B., and Medagedara, S.C. (2011b). Epidemiological Factors Associated with Spotted Fever Rickettsioses in the Central Province, Sri Lanka. Proceedings of Peradeniya University Research Sessions P 101.

Weinberg, M., Keysary, A., Sandbank, J., Zaidenstein, R., Itzhaki, A., Streger,C., Leitner, M., Paddock, C.D. and Eremeeva, M.E.(2008). Fatal Rickettsia conorii subspisraelensis infection, Israel. Emerging Infectious Diseases 14 (5), 821-824.

Wilson, M.L, Levine, J.F, and Spielman, A. (1984). Effect of deer reduction on abundance of the deer tick (Ixodes dammini). Journal of Biology and Medicine 57: 697-705. 
Appendix 1. Wild animals sampled, tick species used to conduct PCR for spotted fever and results

\begin{tabular}{|c|c|c|c|c|}
\hline $\begin{array}{c}\text { Host } \\
\text { (No of hosts tested /collected) }\end{array}$ & $\begin{array}{c}\text { No of ticks } \\
\text { tested/collected }\end{array}$ & Tick species tested & Location & Results \\
\hline \multirow{13}{*}{ Wild boar Sus scrofa (6/6) } & \multirow[t]{13}{*}{$13 / 237$} & A. testudinarium & Thismada & + \\
\hline & & H. hystricis & Thismada & - \\
\hline & & H. isaaci & Thismada & - \\
\hline & & N. monstrosum & Muruthalawa & - \\
\hline & & D. auratus & Muruthalawa & - \\
\hline & & A. testudinarium & Kandy (Polgolla) & - \\
\hline & & A. testudinarium & Thismada & - \\
\hline & & D. auratus & Muruthalawa & - \\
\hline & & H. turturis & Thismada & - \\
\hline & & A. testudinarium & Muruthalawa & - \\
\hline & & H. isaaci & Muruthalawa & - \\
\hline & & A. testudinarium & Kandy (Daulagala) & - \\
\hline & & D. auratus & Kandy (Daulagala) & \\
\hline \multirow{5}{*}{$\begin{array}{l}\text { Pangolin Maniscrassi caudate } \\
(3 / 6)\end{array}$} & \multirow[t]{5}{*}{$05 / 167$} & A. javanense & Thismada & + \\
\hline & & A. clypeolatum & Kandy (Daulagala) & - \\
\hline & & A. testudinarium & Yala & - \\
\hline & & A. clypeolatum & Randenigala & - \\
\hline & & A. javanense & Mihintale & - \\
\hline \multirow{3}{*}{$\begin{array}{l}\text { Star tortoise Geochelone elegans } \\
(3 / 11)\end{array}$} & \multirow[t]{3}{*}{$03 / 71$} & A. clypeolatum & Gampola & - \\
\hline & & A. clypeolatum & Wasgamuwa & + \\
\hline & & A. clypeolatum & Mihintale & - \\
\hline \multirow{5}{*}{$\begin{array}{l}\text { Barking deer Muntiacus muntjak } \\
(4 / 4)\end{array}$} & \multirow[t]{5}{*}{$05 / 66$} & R. sanguineus & Kandy (specify) & - \\
\hline & & A. clypeolatum & Randenigala & - \\
\hline & & H. turturis & Badulla (Katawala) & - \\
\hline & & $R$. sanguineus & Badulla (Kaluthota) & - \\
\hline & & H. kyasanurensis & Badulla (Katawala) & - \\
\hline \multirow{6}{*}{$\begin{array}{l}\text { Mouse deer Moschiola meminna } \\
(6 / 8)\end{array}$} & \multirow[t]{6}{*}{$06 / 267$} & H. aculeata & Thismada & - \\
\hline & & A. javanense & Kandy(Hantana) & - \\
\hline & & H. cuspidata & Randenigala & - \\
\hline & & H. isaaci & Muruthalawa & - \\
\hline & & $R$. sanguineus & Galaha & - \\
\hline & & $R$. sanguineus & Kandy (Peradeniya) & - \\
\hline \multirow[t]{7}{*}{ Porcupine Hystrix indica $(6 / 6)$} & \multirow[t]{7}{*}{$07 / 49$} & H. kyasanurensis & Hantana & - \\
\hline & & H. spinigera & Kandy (Aruppola) & - \\
\hline & & $R$. sanguineus & Kandy (Peradeniya) & - \\
\hline & & A. javanense & Kandy (Hantana) & - \\
\hline & & R. sanguineus & Thalathuoya & - \\
\hline & & $R$. sanguineus & Randenigala & - \\
\hline & & H. kyasanurensis & Udawalawa & - \\
\hline $\begin{array}{l}\text { Samber Rusa unicolor unicolor } \\
(2 / 2)\end{array}$ & $01 / 38$ & H. spinigera & Randenigala & - \\
\hline \multirow{3}{*}{$\begin{array}{l}\text { Spotted deer Axis axis ceylonensis } \\
(3 / 3)\end{array}$} & \multirow[t]{3}{*}{$03 / 301$} & H. isaaci & Sithulpauwwa & - \\
\hline & & H. cuspidata & Buttala & - \\
\hline & & $R$. sanguineus & Randenigala & - \\
\hline $\begin{array}{l}\text { Toque Monkey Maccaca sinica } \\
(1 / 1)\end{array}$ & $01 / 04$ & $R$. sanguineus & Kandy (Peradeniya) & - \\
\hline Civet cat Paradox urus $(1 / 2)$ & $01 / 28$ & H. cuspidata & Kandy (specify) & - \\
\hline Bandicoot Bandicota sp. (1/1) & $01 / 12$ & I. petauristae & Kandy (specify) & - \\
\hline $\begin{array}{l}\text { Asian Elephant Elephas maximus } \\
(1 / 2)\end{array}$ & $01 / 06$ & A. clypeolatum & Kandy (Yala) & - \\
\hline $\begin{array}{l}\text { Fishing cat Prionailurus } \\
\text { viverrinus }(1 / 3)\end{array}$ & $01 / 14$ & H. cuspidata & Kandy (Hantana) & - \\
\hline
\end{tabular}


Rabbit Lepus nigricollis (1/4)

$01 / 61$

$R$. sanguineus

Kandy(Udaperadeniya)

Flying squirrel Petaurista

$01 / 04$

H. cuspidata

Kandy (Kandy) petaurista (1/1)

\begin{tabular}{|c|c|c|c|c|}
\hline Total & 50 & & & 3 \\
\hline $\begin{array}{l}\text { Host } \\
\text { No. of hosts } \\
\text { tested /collected }\end{array}$ & $\begin{array}{c}\text { No. of ticks } \\
\text { tested/no of ticks } \\
\text { collected }\end{array}$ & Tick species tested & Location & Results \\
\hline \multirow[t]{20}{*}{$\begin{array}{l}\text { Dog } \\
15 / 933\end{array}$} & $20 / 9016$ & $R$. sanguineus & $\begin{array}{l}\text { Kandy } \\
\text { (Daulagala) }\end{array}$ & - \\
\hline & & R. haemaphysaloides & $\begin{array}{l}\text { Kandy } \\
\text { (Daulagala) }\end{array}$ & - \\
\hline & & R. microplus & Muruthalawa & - \\
\hline & & $R$. sanguineus & Muruthalawa & - \\
\hline & & H. intermedia & Muruthalawa & - \\
\hline & & $R$. sanguineus & Thismada & - \\
\hline & & $R$. sanguineus & Thismada & - \\
\hline & & H. intermedia & Thismada & - \\
\hline & & R. sanguineus & $\begin{array}{l}\text { Kandy } \\
\text { (Haragama) }\end{array}$ & - \\
\hline & & $R$. sanguineus & Hemmathagama & + \\
\hline & & H. bispinosa & Hemmathagama & - \\
\hline & & H. intermedia & Hemmathagama & - \\
\hline & & R. sanguineus & $\begin{array}{l}\text { Kandy } \\
\text { (Peradeniya) }\end{array}$ & - \\
\hline & & R. microplus & $\begin{array}{l}\text { Kandy } \\
\text { (Peradeniya) }\end{array}$ & - \\
\hline & & $R$. sanguineus & Kandy (Hantana) & - \\
\hline & & R. microplus & Kandy (Hantana) & - \\
\hline & & H. bispinosa & Kandy (Hantana) & - \\
\hline & & $R$. sanguineus & Galaha & - \\
\hline & & H. bispinosa & Galaha & - \\
\hline & & R. microplus & $\begin{array}{l}\text { Kandy } \\
\text { (Katugastota) }\end{array}$ & - \\
\hline \multirow[t]{2}{*}{$\begin{array}{l}\text { Human } \\
10 / 45\end{array}$} & $10 / 45$ & $\begin{array}{l}\text { D. auratus ( } 5 \text { ticks } \\
\text { pooled) }\end{array}$ & Kandy & - \\
\hline & & $\begin{array}{l}\text { A. testudinarium ( } 5 \\
\text { ticks pooled ) }\end{array}$ & Kandy & - \\
\hline Total & 30 & & & 1 \\
\hline
\end{tabular}

